\title{
Democracy Value Based Inquiry Model Development to Enrichment of Critical Thinking in Civics Education
}

\author{
Sulistyarini \\ Civic Departement. Universitas Tanjungpura \\ Pontianak, INDONESIA \\ purnamag5@yahoo.co.id
}

\begin{abstract}
The teaching process of civics education at schools which tends to be teacher centered that without our knowing it may put an end to students' courage to take initiative, kill the desire on their part to express their opinions and bear any resultant consequences, are not ready to enter into arguments and have different opinions and less able to live in diversity. This research aimed to develop teaching inquiry model basing on value/democracy towards enrichment of students' critical thinking ability in the teaching learning of civics education. This study used qualitative approach. Data collection is carried out through observations, in-depth interviews and documentary studies. The results of this research indicate that value/democracy based inquiry model being developed is the teaching, learning model of civics education emphasizing on the process of search and find oneself the answer to a problem. The learning phases consequently applied are: orientation, formulation of problems, hypothesis formulation, data collection, hypothesis testing and drawing of conclusions. In its implementation, students are positioned as learners and teachers as questioners, facilitators, motivators and administrators. Teachers make every effort possible to create a responsive and interesting and enjoyable situation to the students. In the course of studies, teacher's guide and direct students by applying the values of freedom, responsibility, and agreement, pluralistic and tolerant.
\end{abstract}

Keywords: democracy values, inquiry model, critical thinking.

\section{INTRODUCTION}

Civic education is a study program which focuses on the variety of the formation of oneself to be an intelligent and competent Indonesian citizen who possesses good character based on politics, religions, socio-cultures, languages, ages, and races as proposed in Pancasila and UUD 1945. This study program functions as political education which forms an ideology of intelligent and competent Indonesian citizens who are loyal to the country by reflecting on their custom of thinking and behaving based on Pancasila and UUD 1945 (Fajar, 2004:15)

Based on the function mentioned above, teaching and learning process of civic education should be dynamic and be able to attract students' attention in order to make it meaningful. However, it is still common to find that most civic education classrooms are teacher-centered. The methods and techniques in the classroom are monotone and conventional which cause boredom to the students and make them not interested in learning the lesson.
In the teaching and learning process, students are demanding to use their critical thinking skills. Students are expected to construct their own knowledge and understanding so that they do not depend on the teacher. Critical thinking skill is definitely important for the students to compete globally and face the challenges which may happen in the future. Besides that, critical thinking skill is one of the basic or intellectual provisions which is fundamental in human maturity and should be trained continuously as their intellectualities are growing (Ibrahim, 2007: 3).

Based on the literature review, students' critical thinking skills can be trained through student-centered learning. One of the approaches in student-centered learning is inquiry. Oemar Hamalik (2001:220) stated that inquiry is a student-centered learning approach where students observe an issue and analyze the data gained from the observation to produce students' own discovery of information or knowledge.

\section{A. Figures of Inquiry Learning Approach}

Beyer (1971:10) defined inquiry as,"... a guest for meaning that requires one to Perform Certain Intellectual Operations in order to make experience".

Aullsdan Shore (2008:144) stated that an inquiry is: (a) An Instance of seeking truth, (b) Investigation by exhaustive study and (c) A prolonged and careful using actual conditions or primary source of information. Learning process based on inquiry approach first developed by Richard Suchman in 1962 (Joyce, 2000). He wanted the students to question why something happened and then he taught them the procedures and how to use knowledge organization and general principals. Students did the activities, collected and analyzed the data, until they discovered the answers.

OemarHamalik (2001:220) stated that the inquiry is a student-centered learning approach where the students are presented with an issue and then they find the answers from the issue through an observation. Furthermore, Joyce (2000:176) also stated that the inquiry approach demands the students to participate actively in the process of scientific observation. Students are curious and they want to develop their knowledge. Therefore, inquiry approach gives specific guidance for the students and also the opportunity to explore the new knowledge better.

Beside inductive, another characteristic of inquiry approach is process skills. It has been admitted that the 
ability to form a concept is one of the basic thinking skills. Inductive thinking model was designed and developed by Hilda Taba (1966) which intended to encourage the students to discover and organize information, create a concept, and explore various ways that could make the students skilled in organizing the information and assessing the hypotheses. The steps of inquiry are orienting, formulating the problem, formulating hypotheses, collecting data, verifying data, and making the conclusion

The very first basic idea behind the development of democratic education and learning emerged from Adler, 1982 (in Paul Suparno, 1999: 33), which expressed the relationship between education and democracy. He stated that in a democratic country, every citizen is involved in the development of the country and have the same and equal rights and obligations. The second basic idea was from John Dewey (in Paul Suparno, 1999:34) in his book entitled Democracy and Education which simply stated that democratic education and learning is not only to prepare students for their future life in society, but the school itself should be a miniature of the society in which democracy also needs to be held. Therefore, the students do not merely study to prepare for their future, but also truly live democratically in school.

According to Dewey, democracy is a way of living together in which decisions are made jointly by the citizens in a discovery process. A law or a rule must be tested empirically. It does not apply rigidly forever because it should be revised all the time to make sure that the rule or law is still matched with the society needs. Democracy is a means, not an end.

Democratic learning is a two-way interaction between the teacher and the students. The teacher presents the material by giving the students a chance to react and to respond. On the other hand, students can ask several questions or speak up their opinion without any hesitation. Even if necessary, the students may refute the information or teacher's opinion if they have other information.

Learning outcome basically is a collaboration between materials, teacher's opinion, and students' experiences. In the learning process, students play an important role as the subject, not merely an object waiting to be spoon-fed by the teacher.

Ennis (1985) stated that critical thinking is a way of thinking logically and thoroughly to focus more on what to believe or to do. According to Moore and Parker (Glatthorn, 1985: 49) critical thinking is a wise and careful move in deciding whether the decision or research of a phenomenon is accepted, rejected, or cancelled. In addition, critical thinking is a manifestation of the directed thinking, which in the process one determines something and the mind then is directed to solve the problem. MC. Curdy (Sarwono, 1975) stated that critical thinking is a way of making a decision or selection on a phenomenon. There are five indicators of critical thinking (Ennis in Costa, 1985:54-56) which are: (1) Elementary clarification, (2) Basic support, (3) Inferring, Advanced clarification, and (5) Strategies and tactics.

Therefore, critical thinking in civics education is a way of thinking undertaken by the citizens to get to the rational decision. The decision is based on the empirical facts to show weaknesses at any policy concerning the public interest, which in turn will solve the problem. The purpose critical thinking in civics education is to realize the participation of every citizen to make a more democratic, transparent, and accountable system.

\section{B. Research Methodology}

The methodology of this study was a qualitative approach using a case study. The research site was in SMP Negeri 2 Pontianak located in JalanSelayar Kota Baru, Kecamatan Pontianak Selatan, Pontianak, West Kalimantan.. The site research has a special conditions, their social, cultural background very varieties. Data collection is carried out through observations, in-depth interviews and documentary studies. The target is being the teaching activities in the classroom(s) focusing on the behavior of teachers and students as well as teaching learning atmosphere.

The analysis of data was done by categorizing and classifying it based on logical analysis. The data then was interpreted in the context of the research problem. This research focuses more on the effort to examine the process and the phenomena thoroughly and interrelatedly. Therefore, the researcher used a qualitative approach in conducting the research. McMillan and Schumacher (2001:398) stated that qualitative research is based on the assumption that reality has two sides which are interacting, where the social experiences are exchanged and interpreted by each individual

\section{Research Findings and Discussion}

In general, civic education teacher in the school is able to apply various approaches and facilitate the students to upgrade their critical thinking skills. Inquiry approach based on democratic value as proposed in this research is one of the alternatives that the teacher could use, especially for the IX grade students. It is because of inquiry approach, students construct their own knowledge and understanding in a meaningful learning process.

TABLE I. LEARNING ACTIVITIES WITH DEMOCRATIC VALUESBASED INQUIRY APPROACH

\begin{tabular}{|c|c|c|}
\hline No & $\begin{array}{l}\text { Learning } \\
\text { Phases }\end{array}$ & Activities \\
\hline 1 & Orientation & $\begin{array}{l}\text { The teacher explained the materials and the } \\
\text { objectives of the materials. } \\
\text { The teacher explained the learning process of the } \\
\text { materials. }\end{array}$ \\
\hline 2 & $\begin{array}{l}\text { Formulating } \\
\text { problem }\end{array}$ & $\begin{array}{l}\text { Students formulated the problem with the } \\
\text { teacher's help. } \\
\text { Students were encouraged to ask in order to } \\
\text { clarify the issue. }\end{array}$ \\
\hline 3 & $\begin{array}{l}\text { Formulating a } \\
\text { hypothesis }\end{array}$ & $\begin{array}{l}\text { Students formulated the hypothesis with the } \\
\text { teacher's help. } \\
\text { Debriefing activities between the teacher and the } \\
\text { students to clarify the hypothesis. }\end{array}$ \\
\hline 4 & Collecting the data & $\begin{array}{l}\text { Group discussion to collect the data that would } \\
\text { be used in testing the hypothesis. } \\
\text { Data was presented in students' worksheet. }\end{array}$ \\
\hline 5 & $\begin{array}{l}\text { Testing } \\
\text { hypothesis }\end{array}$ & $\begin{array}{l}\text { Students presented and communicated their } \\
\text { findings. } \\
\text { Students were given a chance to test the } \\
\text { hypothesis. }\end{array}$ \\
\hline 6 & $\begin{array}{l}\text { Making } \\
\text { conclusion }\end{array}$ & Students made a conclusion with teacher's help. \\
\hline
\end{tabular}


Student-oriented learning process demands active participations from the students. However, it does not necessarily mean that the teacher loses control over the classroom. On the contrary, good relations and cooperations between the teacher and the students determine the success of the learning itself.

Democratic values-based inquiry approach has two effects called instructional effect and nurturanteffect. Instructional effect can be achieved directly by guiding the students through the learning goals. In this case, the learning goals are scientific process and critical thinking skills. Meanwhile, nurturant effects are other learning outcomes achieved directly by the students without any guidance from the teacher. In this research, the nurturant effects are (1) students have willingness to create something, (2) students are highly commited towards the democratic values, (3) students have courage to ask and to speak up their opinion or arguments, (4) students are not afraid of making mistakes, and (5) students are not afraid to differ in opinions while upholding tolerance. Instructional and nurturant effects can be seen in the figure below:

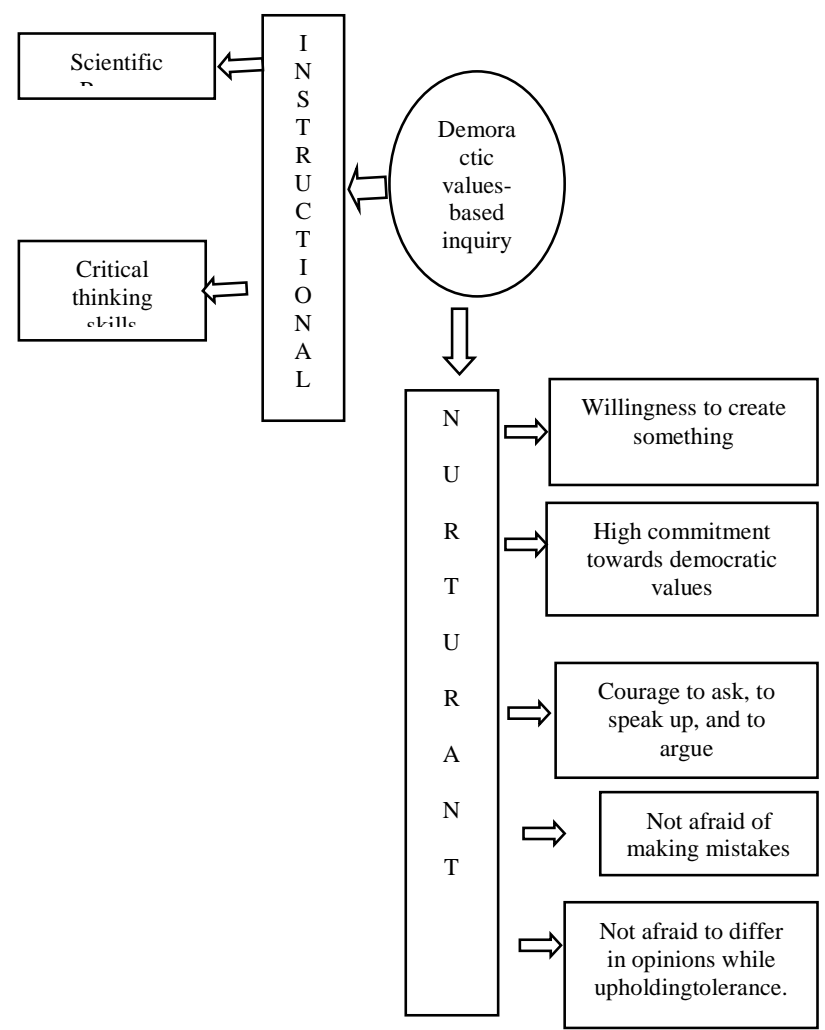

Fig. 1. Instructional and nurturant effects of the democratic valuesbased inquiry approach

From this research, it can be seen that there are several positive changes from the teacher and the students after applying the democratic values-based inquiry approach. One of the significant changes is students have courage to ask or to speak up their opinion. Based on the researcher's observation, students were less likely to speak up their opinion before. Beside that, students are now more confident in answering the questions from the teacher.

Democratic values-based inquiry approach helps students to remember the materials better. Categories of the materials in civic education are closely related to the students' ability to remember the materials as one of the cognitive aspects. Based on the purposes of civic education itself, students' capability to give opinions and to assess something is in line with the knowledge goals in civic education. Democratic values-based inquiry approach is useful in developing students' understanding of the materials.

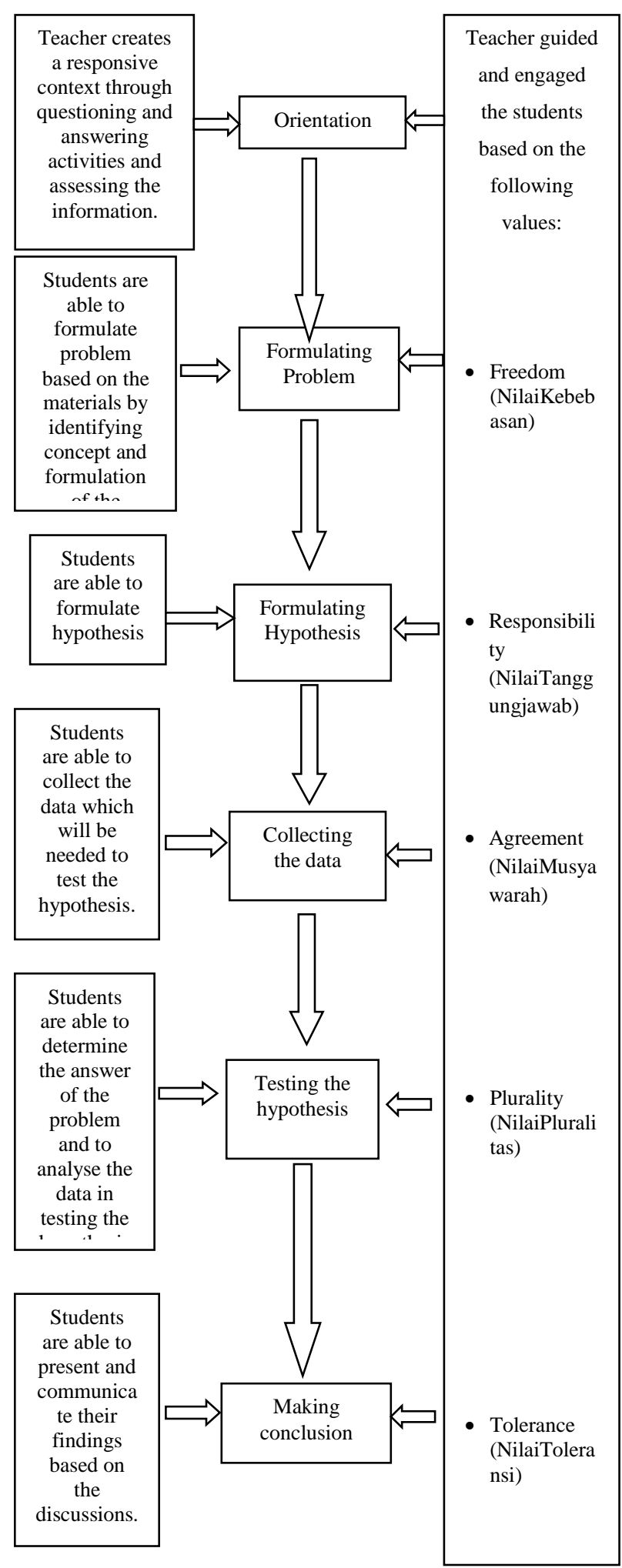

Fig. 2. Result of Democratic Values-based Inquiry Approach at SMP Negeri 2 Pontianak

Another advantage of this approach compared with other conventional learning is that democratic valuesbased inquiry approach stresses on the students' critical thinking skills. Students are facilitated to construct the 
concept through a Dialogic process which insists the students to think critically. The teacher guides the students by asking several questions to stimulate students' thinking skills. Furthermore, teachers also will apply democratic values in the teaching process.

Based on the observation, teacher's ability to explain the learning purposes is also increased. In the pre-activity, for example, a teacher encouraged the students and facilitated them to construct their own knowledge. The teacher was able to relate the materials with the real-life context. The teacher was also able to make a conclusion and to share his/her own experiences to the students.

There are also other developments in teacher's abilities as the result of applying democratic values-based inquiry approach, for example teacher is able to make systematic lesson plans and to facilitate group discussions

Nevertheless, democratic values-based inquiry approach also has several weaknesses, which are: (1) using this approach as the main technique in the classroom will make it difficult for the teacher to control students' activities and achievements, (2) some plans may not work out well because of students' learning habit, (3) it takes longer time to apply this approach compared with other conventional learning approaches.

Based on the learning process and learning outcomes explained before, it can be concluded that using democratic values-based inquiry approach is successful in upgrading students' critical thinking skills in civic education. Democratic values used in this research were: a) Values of Freedom (NilaiKebebasan), b) Values of Responsibility (NilaiTanggungjawab), c) Values of Agreement (NilaiMusyawarah), d) Values of Plurality (NilaiPluralitas), and e) Values of Tolerance (NilaiToleransi).

There were also some steps or stages of democratic values-based inquiry approach, as stated in the following: orientation, formulating the problem, formulating hypothesis, collecting the data, testing the hypothesis, and making conclusions. Design of democratic values-based inquiry approach can be seen in the figure 2 .

\section{CONCLUSION}

Based on the literature review, students' critical thinking skills can be trained through student-centered learning process. One of the approaches is called an inquiry approach. On inquiry approach where democratic value as the guidance, the materials are not directly presented to the students. Students are guided to discover the concept through a Dialogic process which insists the students to think critically.

Based on this research finding, it can be identified that the teacher and the students felt several positive changes after the democratic values-based inquiry approach had been applied. One of the significant changes is the students now are confident to speak up their opinion.

\section{REFERENCES}

[1] Alhakim, S. (2002). Metode DDCT dalam Pembelajaran PPKN di Sekolah Menengah Pertama. Kumpulan Makalah Pengabdian Masyarakat Jurusan PPKn-FIP UM .

[2] Aulls, M. W., \& Shore, B. M. (2008). Inquiry in Education: The Conceptual Foundation for Research as Curricular Imperative. New York: Erlbaum Associates.

[3] Azra, A. (2006). Paradigma Baru Pendidikan Nasional Rekonstruksi dan Demokratisasi. Jakarta: Penerbit Buku Kompas.

[4] Beyer, B. K. (1971). Inquiry in the Social Studies Classroom. Columbia: Charles E Merril Publishing Co.

[5] Budimansyah. (2008). Revitalisasi Pembelajaran Pendidikan Kewarganegaraan Melalui Praktik Belajar Kewarganegaraan (Project Citizen). Jurnal Acta Civicus, I (2), 179-198.

[6] Budimansyah, D., \& Syam, S. (2006). Pendidikan Nilai Moral dalam Dimensi Pendidikan Kewarganegaraan. Bandung: FIPSUPI.

[7] Cholisin, et. al. (2007). Ilmu Kewarganegaraan. Jakarta: Penerbit Universitas Terbuka.

[8] Cogan, J. J. (1999). Developing the Civic Society: The Role of Civic Education. Bandung: CICED.

[9] Cresswell, J. W. (2008). Research Design: Qualitative \& Quantitative Approaches. London: SAGE Publisher.

[10] Ennis, R. H. (1996). Critical Thinking. New York: Prentice Hall.

[11] Fajar, A. (2004). Portofolio dalam Pembelajaran IPS. Bandung: Rosda Karya.

[12] Fisher, A. (2001). Critical Thinking and Introduction. Cambridge: Cambridge University Press

[13] Hamalik, O. (2001). Proses Belajar Mengajar. Jakarta: Bina Aksara.

[14] Joyce, W., \& Calhoun. (2000). Models of Teaching (6th Edition ed.). Boston: Allyn and Bacon.

[15] Karim, R. (1991). Pemilu Demokratis Kompetitif. Yogyakarta: Tiarawacana.

[16] Kerr, D. (1999). Citizenship Education: An International Comparation. London: National Foundation for Educational Research-NFER.

[17] McMillan, J. H., \& Schumacher, S. (2001). Research in Education (5th Edition ed.). United States: Addison Wesley Longman, Inc.

[18] Ibrahim, M. (2007). Pembelajaran Inkuiri. Retrieved 2015, from http://kpicenter.org

[19] Rosyada, D. (2003). Pendidikan Kewarganegaraan (Civic Education), Demokrasi, HAM \& Masyarakat Madani. Jakarta: Kencana Prenada Media Group.

[20] Sudjana, D. (2000). Strategi Pembelajaran. Bandung: Falah Productions.

[21] Suparno, P. (1997). Filsafat Konstruktivisme dalam Pendidikan. Yogyakarta: Kanisius.

[22] Team. (2004). Guru Demokratis di Era Reformasi. Jakarta: Grasindo. 